\title{
Optimization of a Standalone Hybrid Renewable Energy System for Telecom Base Station
}

\author{
Yashwant Sawle* and SC Gupta \\ Department of Electrical Engineering, Maulana Azad National Institute of Technology, India
}

*Corresponding author: Yashwant Sawle, Electrical Engineering Department, Maulana Azad National Institute of Technology, Bhopal, India.

Submission: 非 January 31, 2018; Published: 眥 September 11, 2018

\begin{abstract}
Nowadays, the utility has begun to consider the non-conventional electrical power is pollution free and economic. The non-conventional energy source mobile telecom station is more beneficial as compare diesel operated station. In this paper six different hybrid combinations are investigated on the base of economic, renewable factor, emission for electrified mobile telecom station, HOMER software is used to design hybrid combinations. The output result of HOMER show PV/Wind/Battery/DG system is feasible configuration amongst all six combinations. The PV/Wind/Battery/DG hybrid system has lowest cost of energy $(0.50 \$)$, total net present cost $(\$ 100,666)$ and renewable factor $(100 \%)$.
\end{abstract}

Keywords: Wind turbine; Solar photovoltaic cell; HOMER; Hybrid system

\section{Introduction}

In present day's need of electricity is increase all over the world. The conventional resources of energy are diminishing in future years. The conventional fuel also produces emission which affects environment and human health. To resolve all thus issue renewable energy source is based alternative. Renewable energy source is available abundantly in environment without any cost. India has great potential of renewable energy resource and demand of electricity is increase day by day because of developing economic

Design of the Hybrid System

\section{Load profile}

[1]. The telecom industry of the India is grooving very fast. Presently all the telecom base power station (TBPS) running on diesel generator. The operation of TBPS is very costly due diesel fuel price so that an alternate solution is suggested in paper as renewable energy for source TBPS. The various hybrid combinations for rural location are demonstrated to find the optimal solution regarding cost of energy, reliability, total net present cost and renewable factor. The design location for TBPS has Latitude 19_6350N and Longitude 81_672E which is in Bastar, Chhattisgarh, India.

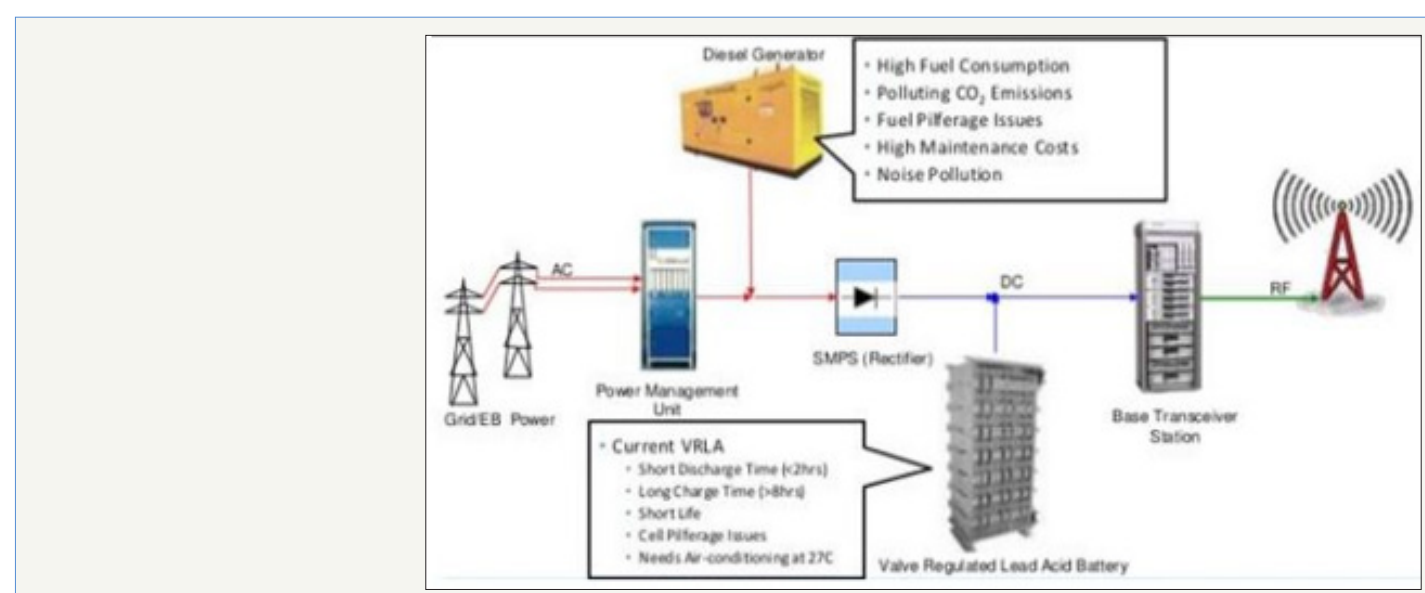

Figure 1: Grid connected and diesel generator telecom base station. 
The TBPS is considered as an essential load. The BTS could be a telecommunication base accustomed encourages remote correspondence between supporter appliance and telecoms administrator system. The worldwide advancement of BTS is increasingly occurring in areas in which the ability conveyance framework often separates for drawn out stretches of time or where there's no entrance to the ability provide the system. That the TPBS in such space, DG with battery unit's area unit used to maneuver down the network for power provide and guarantee system accessibility. Nonetheless, these oblige associate abnormal state of support work and devour moderately high measures of diesel oil for low-level yields. Consequently, DG acquire higher working price. The cost of energy is increase because of change in cost of fuel and issues over obtaining emission have created the telecom organizations to focus on improved power administration routines. This power provides the theme for grid connected and the diesel generator telecom base station is pictured in Figure 1 this technique delivers very high expense due to heavy reliance on diesel generator and worse performance of batteries [2]. Within this recommended method telecom base section regarded as fill considered since $49.77 \mathrm{kWh} / \mathrm{d}$ as well as peak fill regarding day, time is $4.42 \mathrm{~kW}$. The info had been tested to the get worse per hour assumption every day fill requirement of an old-fashioned TBSP. The information was calculated to aggregate hourly premise everyday energy demand prerequisite for rustic telecom. Daily, seasonal and yearly profiles of load data are shown in Figure 2.

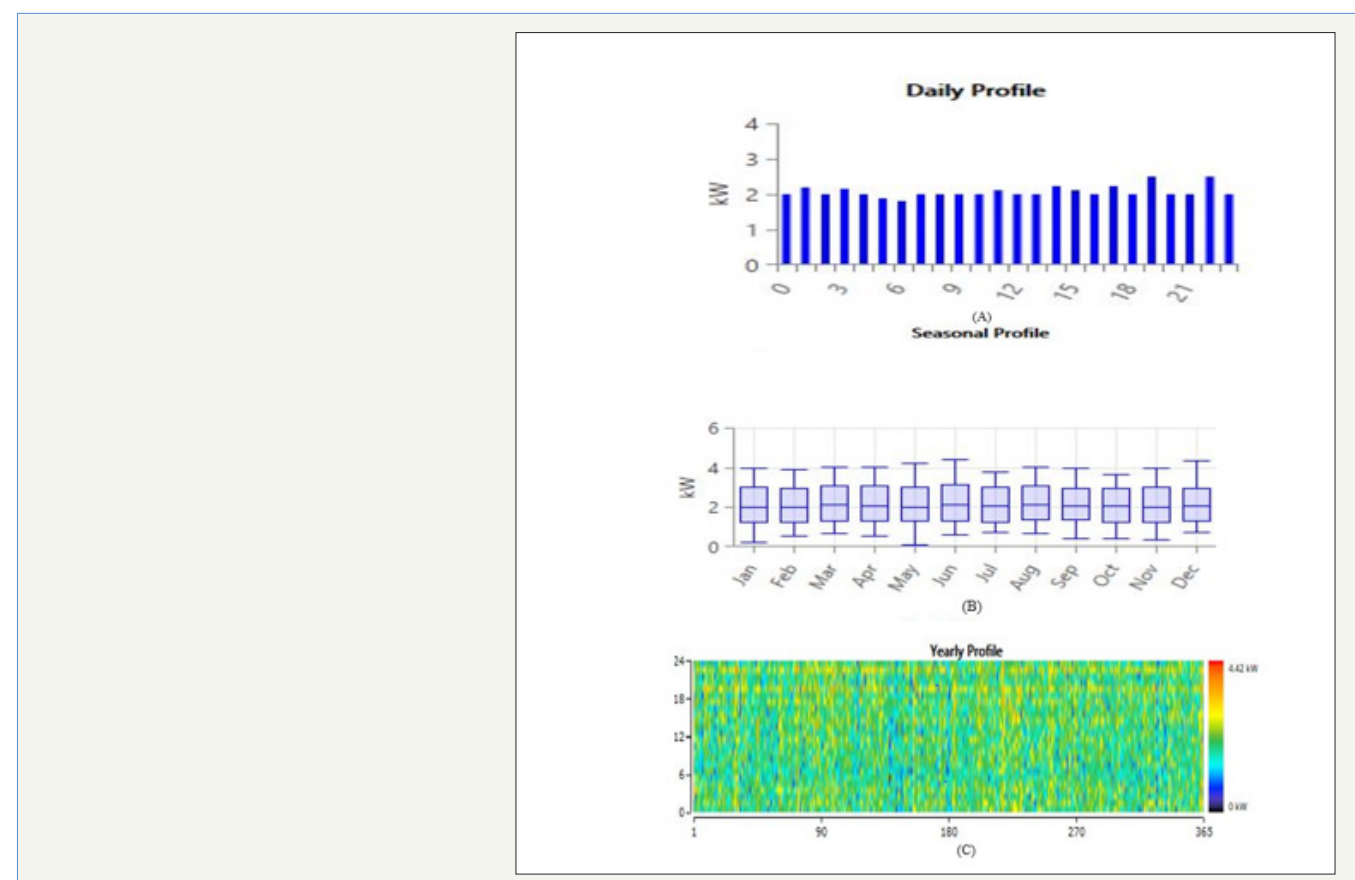

Figure 2: Daily, quarterly and yearly profile of load data.

\section{Solar resource}

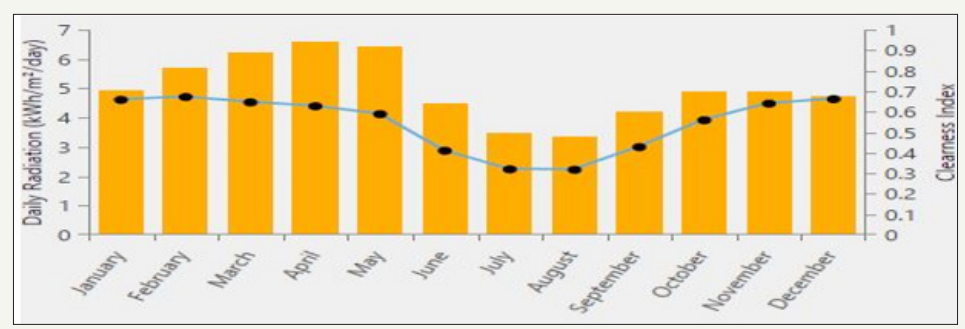

Figure 3: Global horizontal radiation and clearness index.

The PV resource data used for planned hybrid installation at a site of 19_590N latitude and 81_590E of longitude information from NASA Meteorology. The annual average solar irradiation and also the average clearness index were found to be $4.99 \mathrm{kWh} / \mathrm{m}^{2} /$ Day and 0.530 severally. The actual photovoltaic radiation is available whole year round; therefore, an outsized deal of photovoltaic energy productivity is obtained it's pictured in Figure 3. The utmost solar power obtains in summer season [3]. A $5 \mathrm{~kW}$ solar photovoltaic array is linked in series parallel while using the recommended hybrid system. At the position, if the sun rays strike SPV panels, it provides electrical power. Regarding recommended hybrid system, set up charge in addition to replacing charge is usually $\$ 5000$ in addition to $\$ 3000$ from the $1 \mathrm{~kW}$ solar panel. The SPV attached to DC hyperlink and also the de-rating factor from of the array is $80 \%$. Slope, the ground reflectance in percentage and azimuth (Degrees West to East) are 19.9833, 20 and 0 respectively. The weather data of proposed hybrid system location shown in Table 1. 
Table 1: Monthly solar data.

\begin{tabular}{|c|c|c|c|}
\hline S. No & Month & Clearness Index & $\begin{array}{c}\text { Daily Radiation } \\
\left(\mathbf{k W h} / \mathbf{m}^{\mathbf{}} \mathbf{/ d}\right)\end{array}$ \\
\hline 1 & January & 0.658 & 4.93 \\
\hline 2 & February & 0.674 & 5.71 \\
\hline 3 & March & 0.648 & 6.25 \\
\hline 4 & April & 0.628 & 6.61 \\
\hline 5 & May & 0.589 & 6.42 \\
\hline 6 & June & 0.41 & 4.5 \\
\hline 7 & July & 0.319 & 3.48 \\
\hline 8 & August & 0.317 & 3.36 \\
\hline 9 & September & 0.426 & 4.22 \\
\hline 10 & October & 0.556 & 4.89 \\
\hline 11 & November & 0.637 & 4.9 \\
\hline
\end{tabular}

\begin{tabular}{|c|c|c|c|}
\hline 12 & December & 0.661 & 4.73 \\
\hline 13 & Average & 0.53 & 4.994 \\
\hline
\end{tabular}

\section{Wind turbine}

The Wind energy resource data is shown in Figure 4 the average wind speed data throughout the year [4-10]. BWC Excel-R (XLR) turbine is used in the suggested hybrid renewable system. Avail of power as of the wind turbine relies incredibly on wind variation. In this manner, the wind rotary engine rating is by and massive a lot of higher contrasted with the traditional electricity demand. During investigation, Wind Power's XLR design is thought of. The lifespan of a wind turbine is to be twenty years. The rated capacity of this turbine $7.5 \mathrm{~kW}$ DC. The installation cost, replacement and maintenance price of this rotary engine are $\$ 1500, \$ 1200$ and $\$ 75$ respectively. The wind turbine power curve and wind variation with height are shown in Figure 5a \& 5b.

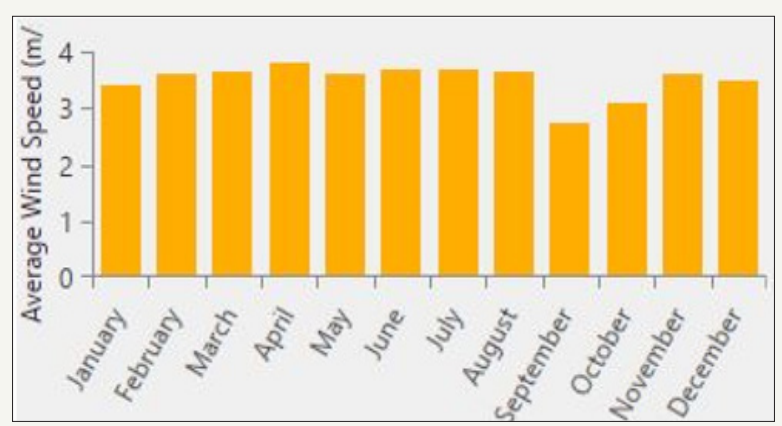

Figure 4: Average monthly wind speed curve.

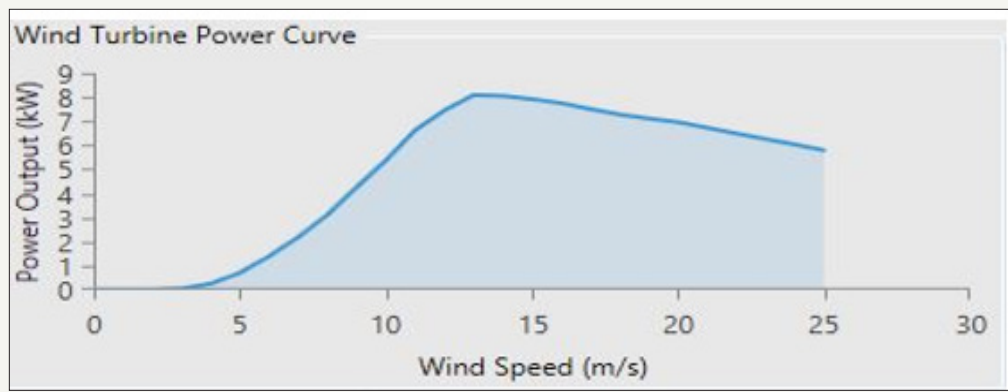

Figure 5a: Wind turbine power curve.

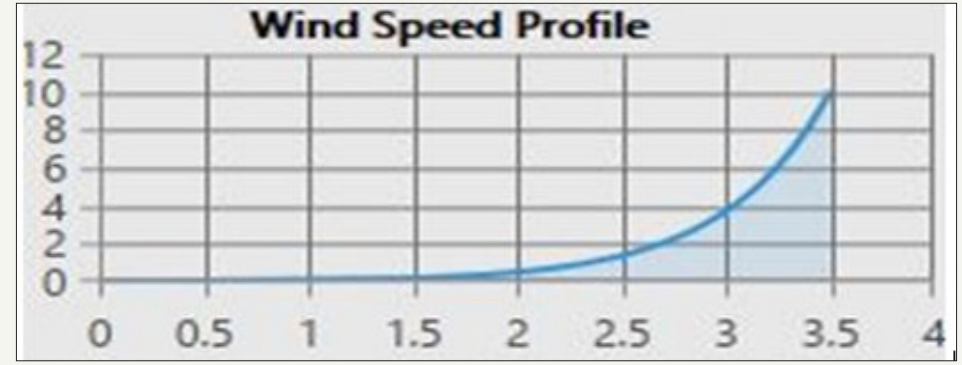

Figure 5b: Wind variation with height.

\section{Diesel generator (DG)}

The size of the generator is $1 \mathrm{~kW}$ recognized as for a hybrid system. The principal cost, replacement cost and O\&M cost of the generator is usually $\$ 325, \$ 225$ along with $\$ 0.520$ respectively. Fuel used for the generator is usually a diesel engine along with the money necessary for diesel-engine usually varies according to overseas current market situation. The variation in diesel price 
is used for sensitivity examination as well as dissimilar values of diesel fuel cost are $0.8 \$ / \mathrm{L}, 0.85 \$ / \mathrm{L}$, and $0.89 \$ / \mathrm{L}$ is introduced. The life of generator is usually consumed since 15,000 operating hours. HOMER guarantees this aggregate functioning pace of the generator in view of the measure of the time this should be used as part of 12 months. The minimum load ratio is $30 \%$. Intercept Coefficient is
$0.08 \mathrm{~L} / \mathrm{hr} / \mathrm{kW}$ rated and the slope (marginal fuel consumption of the generator) is $0.25 \mathrm{~L} / \mathrm{hr} / \mathrm{kW} /$ output. The generator is plugged in to the AC side of the HOMER design model and size for the feasible optimal system are $1 \mathrm{~kW}, 2 \mathrm{~kW}, 5 \mathrm{~kW}$ and $10 \mathrm{~kW}$ considered. The relation between efficiency and output of the generator and fuel curve are shown in Figure 6a \& 6b.

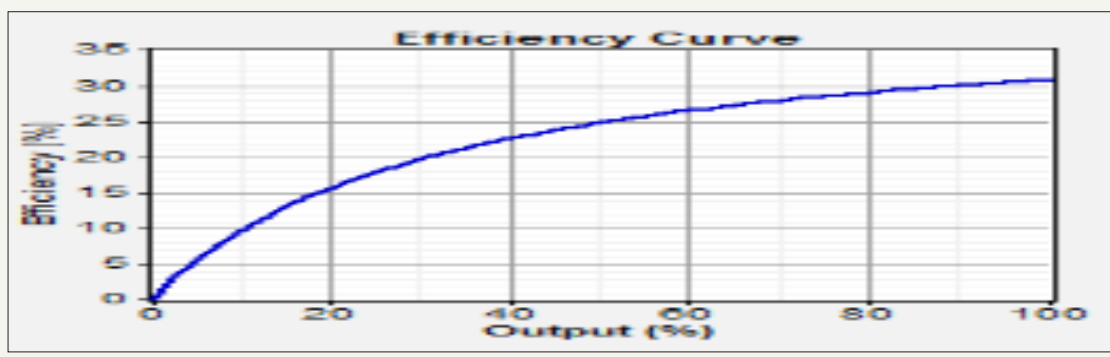

Figure 6a: Generator efficiency curve.

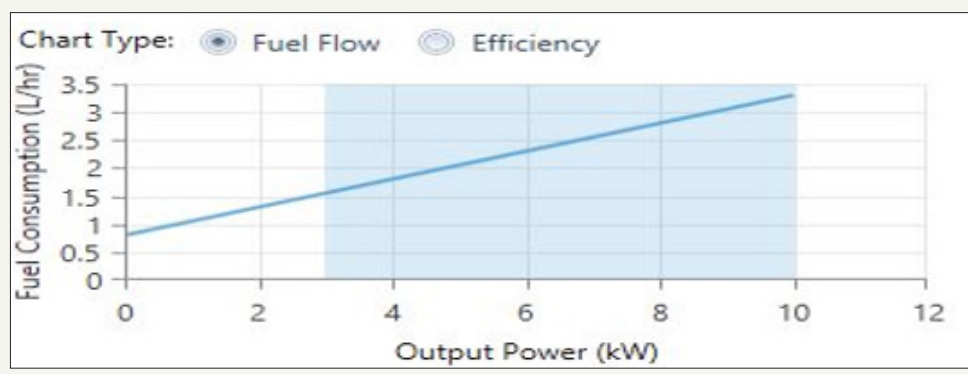

Figure 6b: Fuel curve.

\section{Battery}

The proposed technique is off-grid one in order that some sort of battery power standard bank can be used for just a backup technique along with which in turn additionally keeps regular voltage across the load. The vision 6FM200D battery power can be used to optimum hybrid system [11-15]. The item is comprised $12 \mathrm{~V}, 198 \mathrm{Ah}$, along with $2.4 \mathrm{kWh}$; suggested lifespan throughput is $917 \mathrm{kWh}$ along with connected in series/parallel setting. Principal cost, replacement cost and $0 \& M$ cost is $\$ 280,195 \$$ and $\$ 5$ correspondingly. Battery bank state of charge shown in Figure 7.

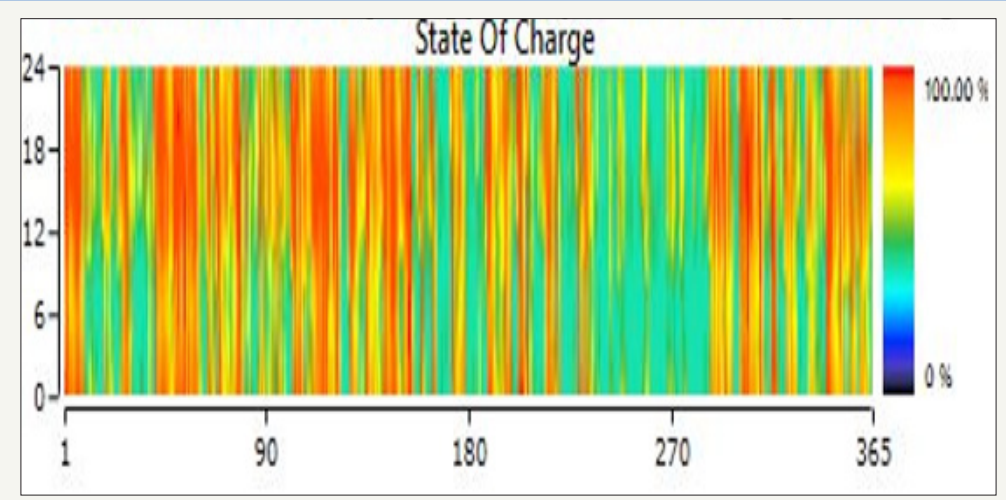

Figure 7: Battery bank state of charge.

\section{Converter}

The particular SPV array output DC at a voltage, which depends on the specific settings along with the sunshine-oriented radiation. The DC control then races to an inverter, which changes over it into standard alternating current (AC) voltage. Inverters often operated as a part of extensive scale applications are main inverters that propose easy establishment and high performance. The sizing of the particular inverter is demand in entering direct current (DC) energy in the SPV and also productivity energy of alternating electric current connected to the particular grid. The proper sizing of inverter possesses skillful to take the most energy from the SPV as well as lower the price of the particular inverter without worrisome the particular operations in the system. The lifespan of the converter is 20 year and efficiency are $90 \%$. Principal cost, replacement cost and $0 \& M$ cost of the converter is .620, 330 and 0.0 respectively [16]. 


\section{Optimization and Simulation}

This section deals with the result of our analysis. The optimization results are presented for different type of six operating modes, which is tracked by results of the sensitivity scrutiny. The proposed system is considered at $5.00 \mathrm{kWh} / \mathrm{m}^{2} /$ day global solar radiation and $3.5 \mathrm{~m} / \mathrm{sec}$ wind speed [17]. The environmental aspect of system configuration is also considered by performing emission analysis. For obtain optimal solution, five different types of PVWind hybrid combinations such as SPV/Batt/DG, WT/Batt/DG, SPV/WT/DG, SPV/WT/Batt and SPV/WT/Batt/DG are analysis. All five-hybrid combination model is shown in Figure 8.

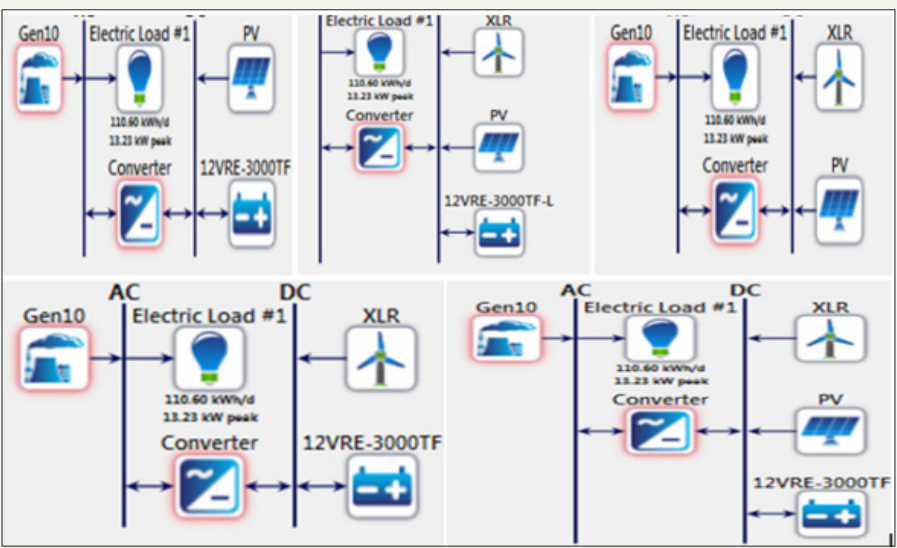

Figure 8: All six combination of hybrid system.

\section{Optimization and Simulation Result}

\section{SPV/Batt/DG}

HOMER performs simulations with respect to a number of inputs given. It identifies the best hybrid system configuration based on several combinations of equipment and their cost and ranks them in ascending order on the basis of least NPC in Figure 9a. A list has been presented for different configurations. Six hybrid configurations have been selected for SPV/Batt/DG connected load.
The first configuration which is the most cost effective one gives the lowest COE of $\$ 0.595 \mathrm{kWh}$ and lowest NPC of $\$ 119,304$ through

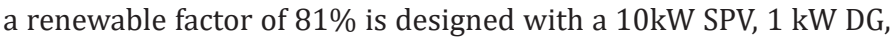
30 battery and $6 \mathrm{~kW}$ converters. The operating and initial cost is $\$ 4,448$ and $\$ 62,445$ respectively. Figure 9b show the monthly average electrical energy output in support of most economic hybrid configuration i.e. the first one. Figure $9 \mathrm{c}$ shows the cash flow summary for various equipment's of the most economic hybrid configuration [18].

\begin{tabular}{|c|c|c|c|c|c|c|c|c|c|c|c|}
\hline \multicolumn{5}{|c|}{ Architecture } & \multicolumn{4}{|c|}{ Cost } & \multirow{2}{*}{$\begin{array}{c}\text { System } \\
\text { Ren frac } 8 \\
(\%)\end{array}$} & \multirow{2}{*}{\multicolumn{2}{|c|}{$\begin{array}{l}\text { Generator } \\
\text { Production }\end{array}$}} \\
\hline$\because \div \boldsymbol{\nabla}{ }_{(\mathrm{KW})}^{\mathrm{PV}} \mathrm{P}$ & $\begin{array}{c}\text { Generator } \\
\text { (kW) }\end{array}$ & $6 F M 20007$ & $\begin{array}{c}\text { Converter } \\
(\mathrm{kW})\end{array}$ & Dispatch $\nabla$ & ${ }_{(5)}^{\operatorname{COE}} \nabla$ & ${ }_{(5)}^{N P C} \nabla$ & $\begin{array}{l}\text { Operating cost } \nabla \\
\text { (5) }\end{array}$ & $\begin{array}{c}\text { Initial capital } \\
\text { (5) }\end{array}$ & & & \\
\hline 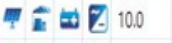 & 1.00 & 30 & 6.00 & LF & $\$ 0.595$ & $\$ 119,304$ & $\$ 4,48$ & $\$ 62,445$ & 81 & 3,356 & 3,053 \\
\hline 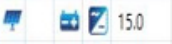 & & 30 & 6.00 & If & $\$ 0.606$ & $\$ 120,512$ & $\$ 2,612$ & $\$ 87,120$ & 100 & & \\
\hline T & 1.00 & 40 & 6.00 & If & $\$ 0.605$ & $\$ 121,478$ & $\$ 4,399$ & $\$ 65,245$ & 81 & 3,333 & 3,031 \\
\hline 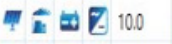 & 1.00 & 30 & 12.0 & LF & 50.617 & $\$ 123,696$ & $\$ 4,500$ & $\$ 66,165$ & 81 & 3,356 & 3,053 \\
\hline 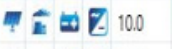 & 1.00 & 50 & 6.00 & Lf & 50.617 & $\$ 123,767$ & $\$ 4,359$ & $\$ 68,045$ & 81 & 3,326 & 3,025 \\
\hline 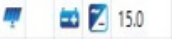 & & 40 & 6.00 & LF & $\$ 0.610$ & $\$ 124,105$ & $\$ 2,674$ & $\$ 89,920$ & 100 & & \\
\hline
\end{tabular}

Figure 9a: A list has been presented for different configurations.

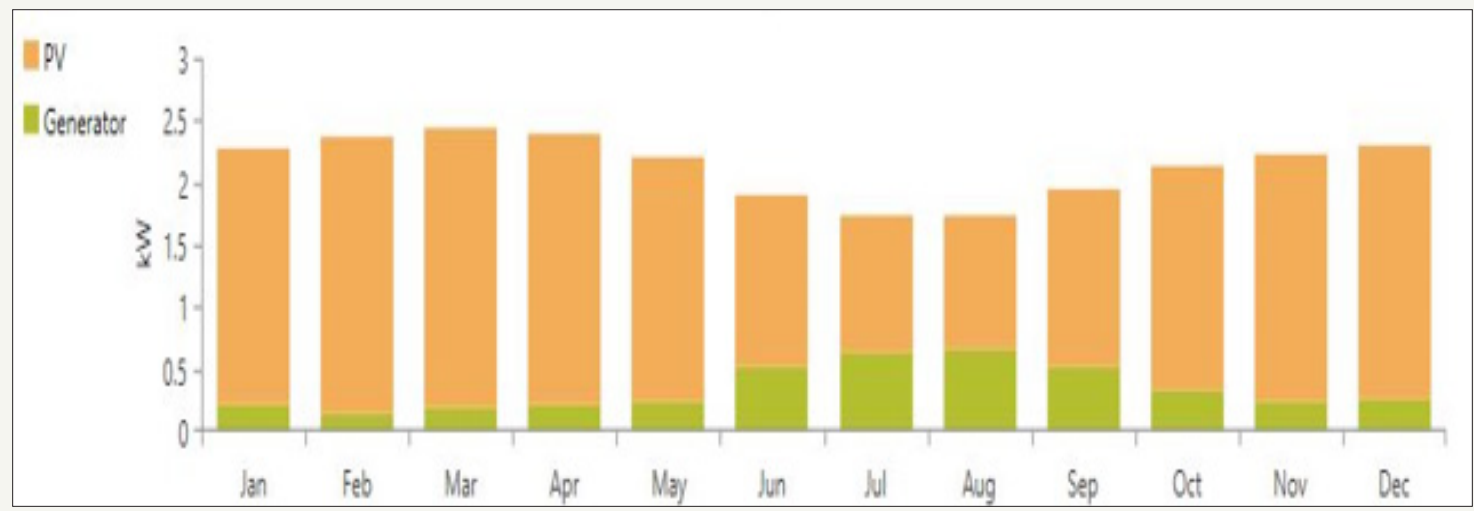

Figure 9b: Shows the monthly average electricity output. 


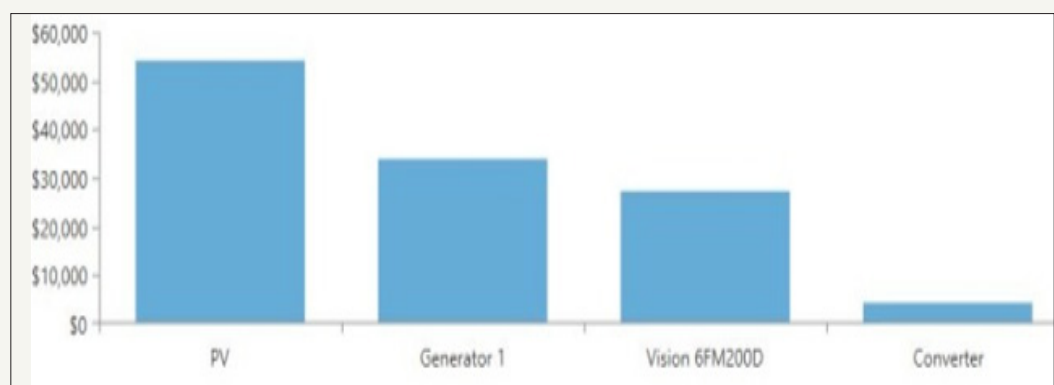

Figure 9c: Shows the cash flow summary for various equipment's of the most economic hybrid configuration.

\section{WT/ Batt /DG}

HOMER performs simulations with respect to a number of inputs given. It identifies the best hybrid system configuration based on several combinations of equipment and their cost and ranks them in ascending order on the basis of least NPC. In Figure $10 \mathrm{a}$ a list has been presented for different configurations. Six hybrid configurations have been selected for WT/Batt/DG connected load.
The first configuration which is the most cost effective one gives the lowest COE of $\$ 0.679 \mathrm{kWh}$ and lowest NPC of $\$ 132,693$ with the renewable fraction of $100 \%$ is configured with a $5 \mathrm{~kW}$ wind, zero diesel generator, 30 battery and $6 \mathrm{~kW}$ converters. The operating and initial cost is $\$ 3,365$ and $\$ 89,620$ respectively. Figure $10 \mathrm{~b}$ shows the monthly average electricity output. Figure 10c shows the cash flow summary for various equipment's of the most economic hybrid configuration.

\begin{tabular}{|c|c|c|c|c|c|c|c|c|c|c|c|c|}
\hline \multicolumn{6}{|c|}{ Architecture } & \multicolumn{4}{|c|}{ Cost } & \multirow{2}{*}{$\begin{array}{c}\text { Spstem } \\
\text { Ren Frac } \\
\left(F_{0}\right)\end{array}$} & \multirow{2}{*}{\multicolumn{2}{|c|}{$\begin{array}{l}\text { Generator } \\
\nabla \text { Production }\end{array}$}} \\
\hline$\Delta+:$ & 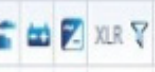 & $\begin{array}{c}\text { Generator } \\
\text { (kW) }\end{array}$ & 6FM2000 8 & $\begin{array}{c}\text { Converter } \\
(\mathrm{kW})\end{array}$ & Dispatch $P$ & ${ }^{C O E} \mathrm{P} P$ & ${ }^{N P C}{ }^{N}{ }^{7}$ & $\begin{array}{l}\text { Operating cost } \\
\text { (5) }\end{array}$ & $\begin{array}{c}\text { Intial capital } \\
\text { (\$) }\end{array}$ & & & \\
\hline t & 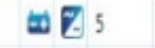 & & 30 & 6000 & LF & 50.679 & $\$ 132,639$ & $\$ 3,365$ & 589,620 & 100 & & \\
\hline 个 & 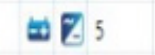 & & 30 & 120 & If & $\$ 0.701$ & $\$ 137,031$ & $\$ 3,418$ & 593,340 & 100 & & \\
\hline$\uparrow$ & $\Leftrightarrow z$ & & 40 & 600 & Lf & $\$ 0.674$ & $\$ 137,089$ & $\$ 3,494$ & 592,420 & 100 & & \\
\hline 个 & 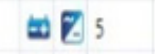 & & 50 & 600 & LF & $\$ 0.674$ & $\$ 141,023$ & $\$ 3,583$ & 595,220 & 100 & & \\
\hline t & $\forall z_{5}$ & & 40 & 12.0 & If & $\$ 0.696$ & $\$ 141,482$ & $\$ 3,547$ & 596,140 & 100 & & \\
\hline$\uparrow$ & $\forall 5$ & & 60 & 6000 & If & 50.677 & $\$ 144460$ & $\$ 3,633$ & 598020 & 100 & & \\
\hline
\end{tabular}

Figure 10a: List has been presented for different configurations

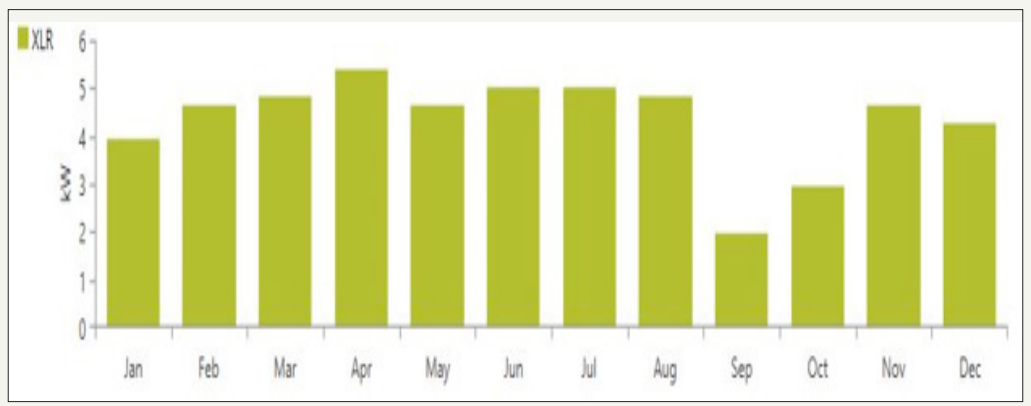

Figure 10b: Shows the monthly average electricity output.

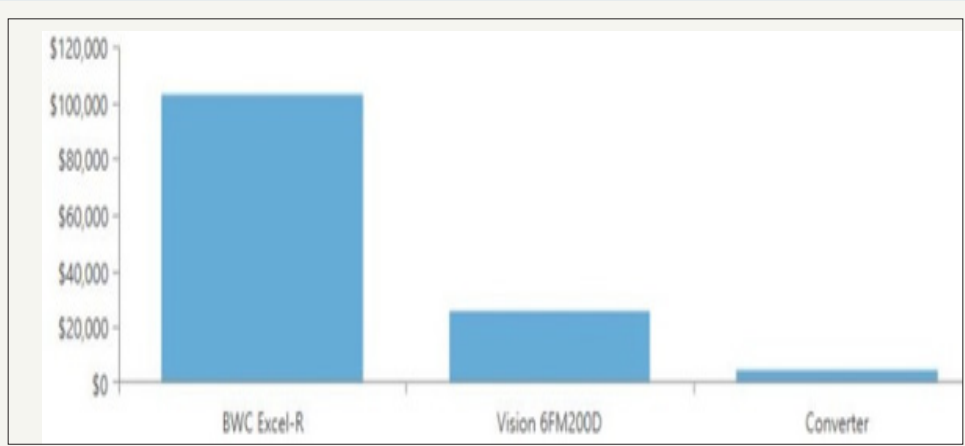

Figure 10c: Shows the cash flow summary for various equipment's. 


\section{SPV/WT/DG}

HOMER performs simulations with respect to number of inputs given. It identifies the best hybrid system configuration based on several combinations of equipment and their cost and ranks them in ascending order on basis of least NPC. Figure 11a a list has been presented for different configurations. Six hybrid configurations have been selected for SPV/WT/DG connected load. The first configuration which is the most cost effective one, gives the lowest COE of $\$ 1.47 \mathrm{kWh}$ and lowest NPC of $\$ 301,870$ with renewable fraction of $81 \%$ is configured with a $10 \mathrm{~kW}$ PV, $10 \mathrm{~kW}$ wind, $1 \mathrm{~kW}$ diesel generator, and $6 \mathrm{~kW}$ converters. The operating and initial cost is $\$ 3,365$ and $\$ 209,045$ respectively. Figure 11 b show the monthly average electricity output for most economic hybrid configuration i.e. the first one. Figure 11c show the cash flow summary for different apparatus of the most economic hybrid configuration. This SPV/WT/DG hybrid system is not feasible solution regarding the stability issue. Renewable penetration has high enough to potential cause stability problem because no storage device in the system.

\begin{tabular}{|c|c|c|c|c|c|c|c|c|c|c|c|}
\hline \multicolumn{5}{|c|}{ Achiecture } & \multicolumn{3}{|c|}{ Cost } & System & \multicolumn{3}{|c|}{ Generator } \\
\hline $\boldsymbol{\nabla}+\boldsymbol{E} \boldsymbol{Z}_{(\mathrm{M})}^{\mathrm{N}}$ & XIRP & $\begin{array}{l}\text { Generator, } \\
\text { (di) }\end{array}$ & Conver & Dispatc & ${ }_{18}^{\cot } 8$ & ${ }_{(S)}^{N P C} \nabla$ Operatin & $\begin{array}{c}\text { Intid capt } \\
\text { (5) }\end{array}$ & Pen froc & Hours 8 & Productio & (l) $P$ \\
\hline 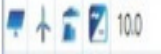 & 10 & 100 & 600 & if & $\$ 1.47$ & $\$ 301,87057,661$ & 5209045 & 81 & 3935 & 3005 & 1066 \\
\hline$\nabla+\square 700$ & 10 & 100 & 120 & if & $\$ 150$ & 530626337,314 & $\$ 212765$ & 81 & 3935 & 3005 & 1066 \\
\hline$\nabla+\square 7150$ & 10 & 100 & 600 & if & $\$ 159$ & $\$ 32672657,250$ & $\$ 234045$ & \& & 3695 & 2064 & 1012 \\
\hline 甲ヤะZ 150 & 10 & 100 & 120 & If & $\$ 1.61$ & $\$ 331,11957,303$ & $\$ 237,765$ & Q & 3695 & 2864 & 1012 \\
\hline $7+\div 200$ & 10 & 100 & 600 & If & $\$ 1.71$ & $5352,54857,314$ & 8259,045 & 83 & 3,559 & 2789 & 982 \\
\hline $7+\leq 7200$ & 10 & 100 & 120 & if & $\$ 1.74$ & $5356,4057,367$ & 5862765 & 83 & 3559 & 2789 & 982 \\
\hline
\end{tabular}

Figure 11a: List has been presented for different configurations.

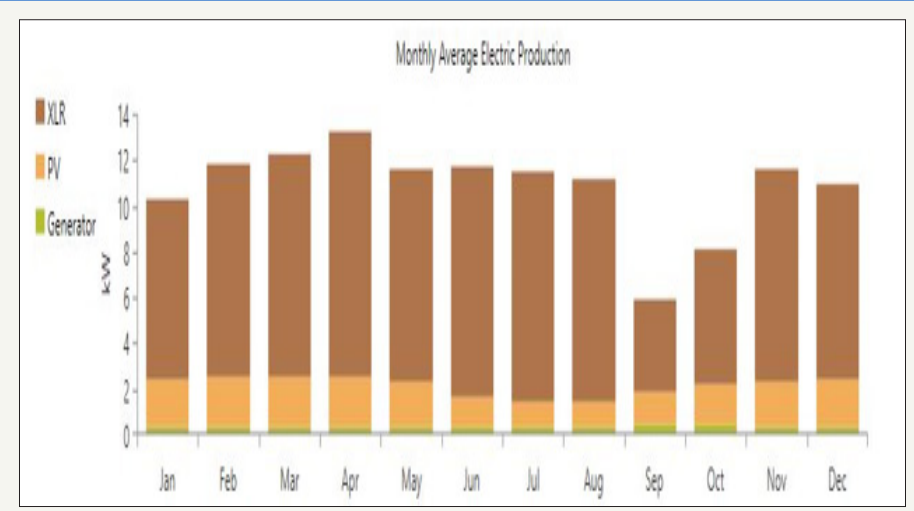

Figure 11b: The monthly average electricity output.

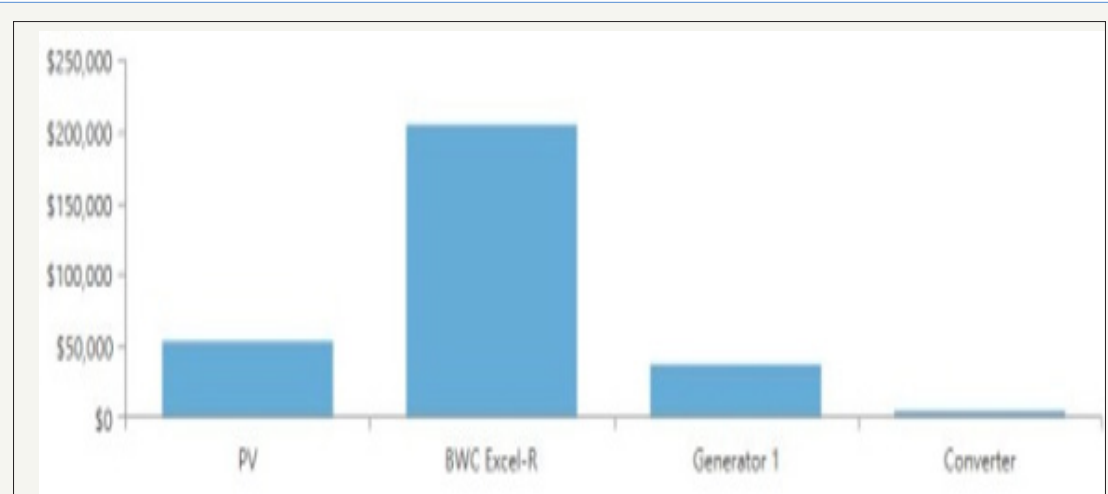

Figure 11c: Shows the cash flow summary for various equipment's of the most economic hybrid configuration.

\section{SPV/WT /Batt}

HOMER performs simulations with respect to number of inputs given. It identifies the best hybrid system configuration based on several combinations of equipment and their cost and ranks them in ascending order on basis of least NPC. In Figure 12a a list has been presented for different configurations. Six hybrid configurations have been selected for SPV/WT /Batt connected load. The first 
configuration which is the most cost effective one, gives the lowest COE of $\$ 0.501 \mathrm{kWh}$ and lowest NPC of $\$ 100,666$ with renewable fraction of $100 \%$ is configured with a $5 \mathrm{~kW}$ PV, $2 \mathrm{~kW}$ wind, 40 battery units and $6 \mathrm{~kW}$ converters. The operating and initial cost is $\$ 2,327$ and $\$ 70,920$ respectively. Figure $12 \mathrm{~b}$ shows the monthly average electrical energy production for most economic hybrid configuration i.e. the first one. Figure $12 \mathrm{c}$ shows the cash flow summary for various equipment's of the most economic hybrid configuration.

\begin{tabular}{|c|c|c|c|c|c|c|c|c|c|c|}
\hline \multicolumn{5}{|c|}{ Architecture } & \multicolumn{3}{|c|}{ Cost } & Syitem & \multicolumn{2}{|r|}{$\mathbb{N}$} \\
\hline $\boldsymbol{\nabla}+\boldsymbol{\nabla} \boldsymbol{Z}_{(\mathrm{KM})}^{\mathrm{NV}}$ & XRP $P$ & GFMECOD ? & $\begin{array}{c}\text { Converter } 8 \\
(W)\end{array}$ & Dispatch $P$ & ${ }_{180}^{\cot } \mathrm{P}$ & ${ }_{(5)}^{N P C} \nabla$ Operating & $\begin{array}{c}\text { Intial ap } \\
(5)\end{array}$ & $\begin{array}{c}\text { Pen firce o } \\
(x)\end{array}$ & Capital cost 8 & 8 Production ? \\
\hline T+口 500 & 2 & 40 & 600 & Uf & $\$ 0501$ & $\$ 100,66652327$ & 50920 & 100 & 25,000 & 7,820 \\
\hline $7+20.00$ & 1 & 20 & 6000 & is & $\$ 0525$ & $\$ 10322352222$ & 574820 & 100 & 50000 & 15640 \\
\hline Th & 2 & 80 & 600 & $v$ & 50508 & $\$ 103,96352,367$ & 573,720 & 100 & 25,000 & 1,820 \\
\hline 甲 $4=\nabla 500$ & 2 & 40 & 120 & If & $\$ 0523$ & $\$ 105059 \$ 2390$ & 574640 & 100 & 25000 & 7820 \\
\hline T+口: 500 & 2 & 60 & 6.00 & U & $\operatorname{sos} 16$ & $\$ 107,208 \Omega, 401$ & 586,520 & 100 & 25,000 & 7880 \\
\hline 甲 小 & 1 & 20 & 120 & U & $\$ 0548$ & $\$ 107,616 \$ 2275$ & 578540 & 100 & 50000 & 15,400 \\
\hline
\end{tabular}

Figure 12a: List has been presented for different configurations.

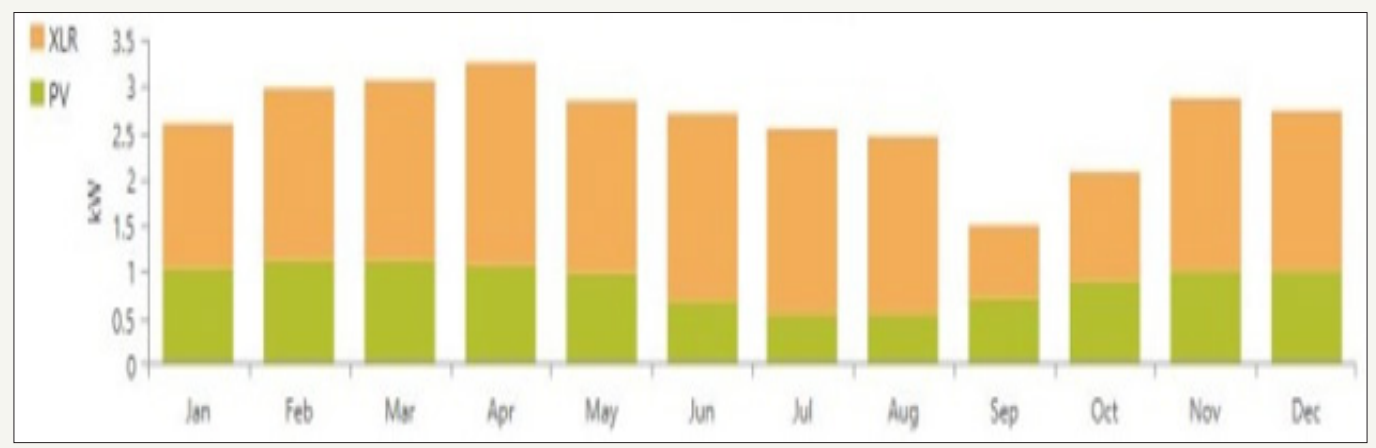

Figure 12b: The monthly average electricity production for most economic hybrid configuration.

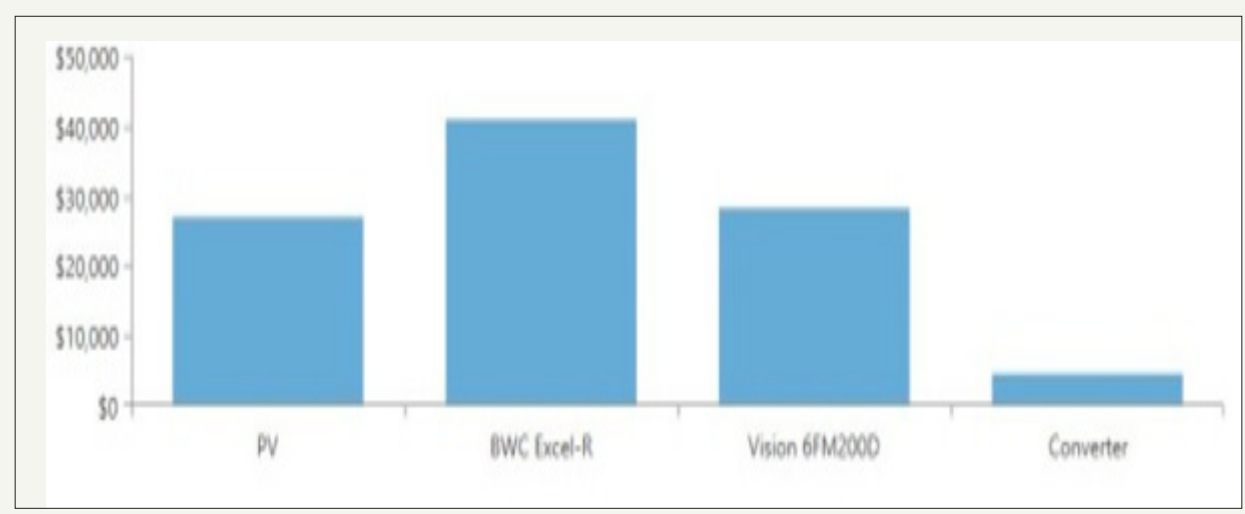

Figure 12c: Shows the cash flow summary for various equipment's of the most economic hybrid configuration.

\section{SPV/WT/Batt/DG}

HOMER performs simulations with respect to number of inputs given. It identifies the best hybrid system configuration based on several combinations of equipment and their cost and ranks them in ascending order on basis of least NPC. Figure 13a a list has been presented for different configurations. Six hybrid configurations have been selected for SPV/WT/Batt/DG connected load. The first configuration which is the most cost effective one, gives the lowest
COE of $\$ 0.544 \mathrm{kWh}$ and lowest NPC of $\$ 110,770$ with renewable fraction of $81 \%$ is configured with a $5 \mathrm{~kW} \mathrm{PV}, 1 \mathrm{~kW}$ wind, $0 \mathrm{~kW}$ diesel generator, 40 battery units and $6 \mathrm{~kW}$ converters. The operating and initial cost is $\$ 4,307$ and $\$ 55,745$ respectively. Figure $13 \mathrm{~b}$ shows the monthly average electricity output for most economic hybrid configuration i.e. the first one. Figure 13c shows the cash flow summary for various equipment's of the most economic hybrid configuration [19]. 


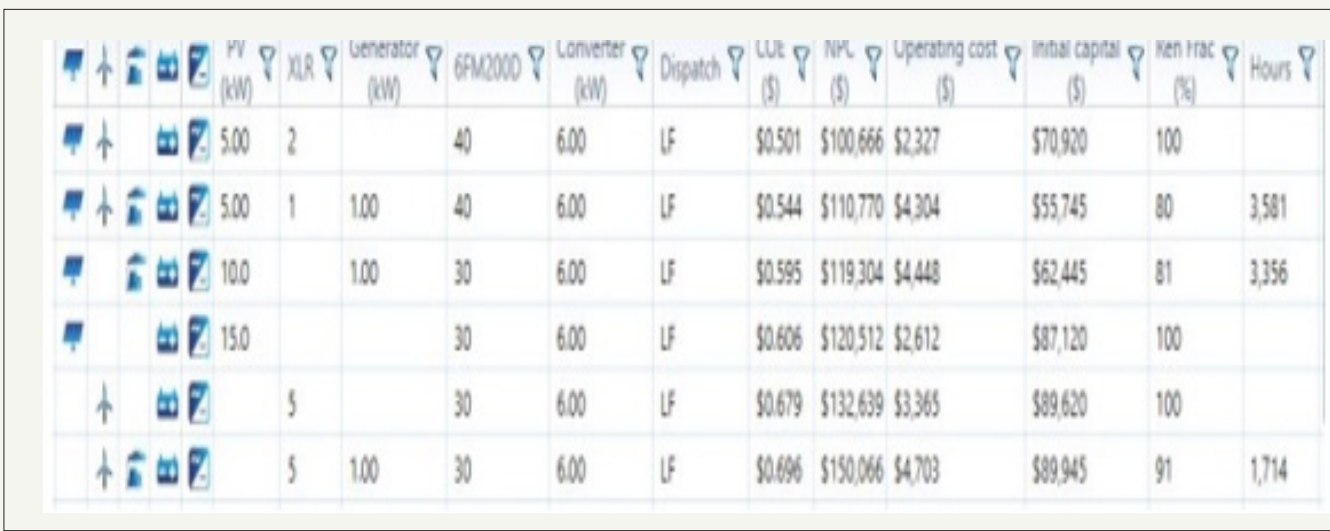

Figure 13a: A list has been presented for different configurations.

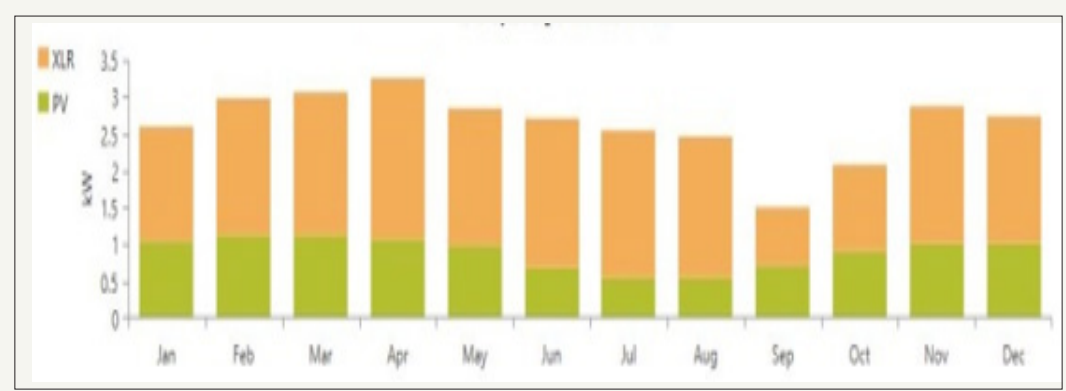

Figure 13b: Shows the monthly average electricity output.

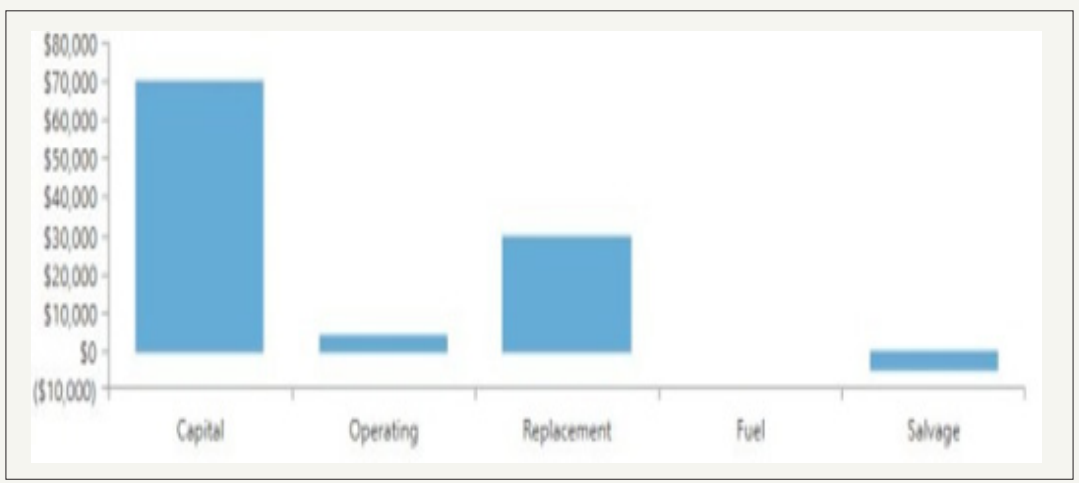

Figure 13c: Shows the cash flow summary for various equipment's.

\section{Result and Discussion}

The design of all combination through the HOMER software tool, which provide simulation results on base of lowest total net present cost, lowest cost of energy, and renewable factor. All sixcombination analysis describe in this section.

a. Emission: Amongst all six combinations only system which not produce any harmful emission such SPV/WT/Batt, SPV/WT/Batt/DG have not produced any gases.

b. Production: According to the simulation analysis, we found that the capability shortage among all told cases is lower in SPV/WT/Batt/DG $(3,161.7)$ and SPV/WT/Batt system in both combinations. It suggested that can be designing to fulfil required load demand. c. Cost (\$): The simulation result, it is analyzed that the system connected with SPV/WT/Batt/DG has lowest total net present cost $\$ 100,666$, levelized cost $\$ 0.5012$ and operating cost $\$ 2327$ as compared to hybrid combinations.

d. Fuel: The DG connected system increase the cost of hybrid system. Above discussed results it is clear that the SPV/WT/ Batt/DG hybrid system has no fuel consumption. So, the SPV/ WT/Batt/DG system is feasible solution.

\section{Conclusion}

Fonts, Because of the relentless development of telecom market and related ventures in India, there's a need to build up another Power supplies. It's actual that the offer of telecom development in provincial territories is a long way from metro cities. In this paper 
various combination of SPV, Wind and DG and Battery hybrid system are investigated for obtaining feasible solution. This investigation found SPV/WT/Batt or SPV/WT/Batt/DG are often feasible as this kind of has no $\mathrm{CO}_{2}$ and $\mathrm{CO}$ emissions. Both the combination has lower cost of energy, total net present cost and environment friendly. SPV/WT/Batt/DG hybrid renewable energy system provide more promising results regarding cost of energy, total net present cost and renewable factor, emission and electrical production amongst all six combination. The simulation results in this paper can play a useful role in the application of hybrid renewable energy system for rural TBPS projects. The obtained results can be modified by reducing the cost of components if central and states government provide subsidy.

\section{References}

1. Dmowski A, Piotor B, Kras B (2001) Hybrid solar panel fuel cell power plant 11: 22-23.

2. Nelson DB, Nehrir MH, Wang C (2006) Unit sizing of stand-alone hybrid wind/PV/fuel power generation systems. Renew Energy 31(10): 16411656

3. Larmine J, Dicks A (2003) Fuel cell systems explained. (2 $\left.{ }^{\text {nd }} e d n\right)$, Wiley, England, UK.

4. Iqbal MT (2007) Modeling and control of a fuel cell hybrid energy system. Renew Energy 28(2): 223-237.

5. Hansen JC, Lundsager P, Nielsen LH (2007) Energy report 4. Risø National Laboratory, Denmark, Europe, pp. 21-27.

6. Doumbia ML, Agbossou K (2009) Photovoltaic/wind energy system with hydrogen system. Renewable Energy, pp. 249-265.

7. Li CH, Zhu XJ, Cao G, Sui S, Hu MR (2009) Dynamic modeling and sizing optimization of stand-alone photovoltaic power systems using hybrid energy storage technology. Renew Energy 39(3): 815-826.

8. Nurul AAR, Muhammad MO, Ismail M (2010) Optimal sizing and operational strategy of hybrid renewable energy system using HOMER. In: Shah Alam, Selangor (Eds.), The $4^{\text {th }}$ International Power Engineering and Optimization Conf. (PEOCO2010), Malaysia, pp. 23-24.
9. Mukhtaruddin RNSR, Rahman HA, Hassan MY (2013) Economic analysis of grid-connected hybrid photovoltaic-wind system in Malaysia. Clean Electrical Power (ICCEP), International Conference, pp. 577-583.

10. Yashwant S, Gupta SC (2015) A novel system optimization of a grid independent hybrid renewable energy system for telecom base station. International Journal of Soft Computing, Mathematics and Control 4(2).

11. Amutha WM, Rajini V (2015) Techno-economic evaluation of various hybrid power systems for rural telecom. Renewable and Sustainable Energy Reviews 45: 553-561.

12. Chong L, Xinfeng G, Yuan Z, Chang X, Yan R, et al. (2013) Techno-economic feasibility study of autonomous hybrid wind/PV/battery power system for a household in Urumqi, China. Energy 55: 263-272.

13. Rehman S, Mahbub AM, Meyer J, Hadhrami LM (2012) Feasibility study of a Wind-PV-diesel hybrid power system for a village. Renewable Energy 38(1): 258-268.

14. Sawle Y, Gupta SC (2014) Optimal sizing of photo voltaic/wind hybrid energy system for rural electrification. Power India International Conference (PIICON), $6^{\text {th }}$ IEEE, Delhi, India 14: 1-4.

15. Vivek T, Gupta SC, Yashwant S (2015) Study of characteristics of single and double diode electrical equivalent circuit models of solar PV module. 2015 International Conference on Energy Systems and Applications, IEEE.

16. Yashwant S, Gupta SC, Aashish KB (2016) PV-wind hybrid system: A review with case study. Cogent Engineering 3(1): 1189305.

17. Yashwant S, Gupta SC (2015) Optimal sizing of a PV/biomass hybrid system with battery, storage for rice mill electrification to an off-grid remote area. Ciencia E Tecnica Vitivinicola Journal 30(3): 173-194.

18. Vivek T, Gupta SC, Yashwant S (2015) Single-diode and two-diode PV cell modeling using matlab for studying characteristics of solar cell under varying conditions. Electrical \& Computer Engineering: An International Journal (ECIJ) 4(2): 67-77.

19. Tamrakar V, Gupta SC, Yashwant S (2015) Study of characteristics of single and double diode electrical equivalent circuit models of solar PV module. Energy Systems and Applications, 2015 International Conference on. IEEE.
Creative Commons Attribution 4.0 International License

For possible submissions Click Here

\section{Submit Article}

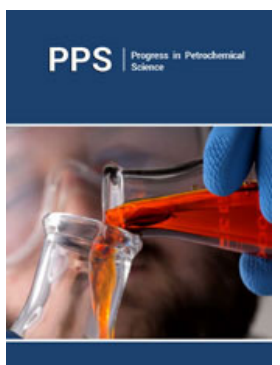

\section{Progress in Petrochemical Science}

\section{Benefits of Publishing with us}

- High-level peer review and editorial services

- Freely accessible online immediately upon publication

- Authors retain the copyright to their work

- Licensing it under a Creative Commons license

- Visibility through different online platforms 